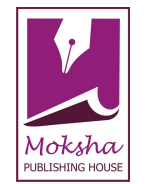

Research Article

www.ijrap.net

\title{
A CLINICAL STUDY TO EVALUATE THE EFFICACY OF GUDUCHYADI KWATH IN THE MANAGEMENT OF DIABETIC POLYNEUROPATHY
}

\author{
Rehana Parveen ${ }^{1 *}$, B. P. Sarma ${ }^{2}$
}

${ }^{1}$ PG Scholar, Department of Kaya Chikitsa, Government Ayurvedic College and Hospital, Guwahati, India

${ }^{2}$ Professor \& HOD, Department of Kaya Chikitsa, Government Ayurvedic College and Hospital, Guwahati, India

Received on: 23/11/15 Revised on: 20/01/16 Accepted on: 28/01/16

\author{
*Corresponding author \\ E-mail: rehana.p866@gmail.com
}

DOI: $10.7897 / 2277-4343.07248$

\begin{abstract}
Incidence of diabetes is escalating globally and approximately 50 percent of patients with diabetes eventually develop neuropathy. The growing sideeffects of modern pharmacological agents are a persuasion to search an amicable solution in Ayurveda. A total of 60 patients of Diabetic Polyneuropathy aged between 20-70 yrs were randomly selected and assigned in two groups. In Group A (Trail group) patients were given Guduchyadi Kwath, 40ml twice daily after meal while those in Group B (Control group) were given Tab Methylcobalamine (500mcg) + Gabapentine (300mg), 1 tab daily for 90 days with 6 follow ups. Assessment was done on the basis of sign and symptoms as mentioned in Ayurvedic and modern classics and objective parameters of Diabetic Neuropathy. It was observed that the resultant improvement in cardinal sign and symptoms were statistically highly significant for Burning sensation, Vibration sensation, Toronto clinical score $(\mathrm{p}<0.001)$ and significant for Numbness, Pin prick test $(p<0.05)$, Tingling sensation ( $p<0.01)$, Monofilament test $(p<0.02)$ while insignificant results were obtained for symptoms of Neuropathic pain, weakness and sign of deep tendon reflex for the Trail drug. On comparing the results obtained for both the groups it is observed that the trail drug, Guduchyadi kwath has equivalent efficacy in DPN as the control drug except for the symptom of neuropathic pain for which the control drug seems to be effective while the trail drug was observed to be ineffective.
\end{abstract}

Keywords: Diabetic polyneuropathy, Guduchyadi Kwath, Vibration sensation

\section{INTRODUCTION}

Diabetes mellitus which is well known to mankind since antiquity, is a serious agonizing disease with detrimental health complications and premature mortality. Globally and across all ages, it is estimated that at least 1 in 20 deaths are attributable to diabetes and its complications. The prevalence of diabetes amongst all age-groups worldwide is presently estimated to be $8.3 \%$. As the incidence of diabetes is escalating globally so is the case with its complications. Diabetic neuropathy is the most common complication of diabetes reaching $45-50 \%$ prevalence compared to $25-30 \%$ of retinopathy and $20 \%$ of nephropathy. Functional and structural impairments of peripheral nervous system due to hyperglycemia are generally defined as diabetic neuropathy and its diagnosis is based on the exclusion of other diseases that may involve nervous system. ${ }^{3}$ Most common among the neuropathies are chronic sensorimotor distal symmetric polyneuropathy (DPN) ${ }^{4} 10$ to 18 percent of patients have evidence of nerve damage at the time their diabetes is diagnosed, suggesting that even early impairment of glucose handling, classified as prediabetes, is associated with neuropathy. ${ }^{5}$

The primary aim of the current diabetes management strategies is to achieve tight blood glucose level control. However, intensive blood glucose control alone does not necessary reduce the risk of developing diabetic vascular complications. The early recognition and appropriate management of neuropathy in the patient with diabetes is important as up to $50 \%$ of DPN may be asymptomatic, and patients are at risk of insensate injury to their feet. The neuropathies developing in patients with diabetes are known to be heterogenous by their symptoms, pattern of neurologic involvement, course, risk covariates, pathologic alterations, and underlying mechanisms $^{6}$. Long term hyperglycemia elicits enhanced polyol pathway, increased nonenzymatic glycation of structural proteins, increased oxidative stress as well as altered protein kinase $\mathrm{C}$ activity and polyADP-ribose polymerase (PARP) activation that are all interrelated for the cause and development of neuropathy. ${ }^{7.8,9}$

The scholars of Ayurveda have studied DM in detail and also the description of Prameha Roga described in all authentic Ayurvedic texts. After careful and detailed study, analysis of all aspects of both disorders, many similarities are found in respect of etiology, pathology, symptomatology and few modalities of treatment. The features such as Karapada Daha (burning sensation), Cumcumayana (tingling sensation), Suptata (numbness) are symptoms seen in Prameha Rogi either in prodromal stage or in the actual exhibition stage or in complication stage, is identified as Diabetic peripheral neuropathy. ${ }^{10}$

Diabetic vascular complications are postulated to be initiated and exacerbated by multiple signaling pathways which are obviously linked to each other in a synergistic order. As herbal medicines possess a mixture of phytochemicals, their role in targeting multiple inflammatory pathways in a synergistic manner could mean that herbal medicines may be an effective solution to the prevention and management of diabetic vascular complications. Nevertheless, there are increased pre-clinical, as well as clinical evidence, to demonstrate the potential of herbal medicines and nutraceuticals in targeting diabetic complications. Moreover, in spite of many advances, the management of DPN is not up to the mark and associated with lots of side effects in conventional system of medicine. 
Keeping all this view in mind Guduchyadi Kwath was under taken to evaluate its clinical efficacy and safety in Diabetic peripheral neuropathy. The research to date opens new opportunities in the development of novel and effective strategies to complement and even add to the current available treatments

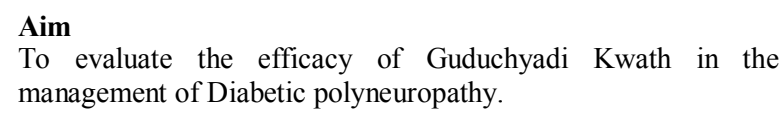

\section{Objectives}

To study the etiopathology, symptomatology and progress of Diabetic polyneuropathy according to Ayurvedic Science as well as Modern Science.

To assess the efficacy of Guduchyadi kwath in the management of this disease by administering the drug orally for a period of 3 months.

To compare the efficacy of the trial drug with a control drug. To explain the rationale behind the formulation designing of the trial drug in this disease.

\section{MATERIALS AND METHODS}

\section{Selection of patients}

60 patients of Diabetic polyneuropathy (satisfying the inclusion criteria) were selected randomly from OPD and IPD of Government Ayurvedic College and Hospital, Guwahati, irrespective of sex, occupation and socio-economic status.

For clinical trial, previously diagnosed patients of diabetes mellitus, who are under treatment with adequate glycemic control were selected and clinically evaluated for symptoms of distal symmetrical polyneuropathy. In presence of clinical symptoms of peripheral neuropathy, the patients in whom at least two of the physical signs are found abnormal, a diagnosis of peripheral neuropathy was considered and were included in the study. They were assigned into two groups viz. Group A (Trial group) and Group B (Control group). A total of 30 patients were registered for each group but 6 patients dropped out from group A and 12 patients dropped out from group B at various stages during the study, finally leaving 24 and 18 number of patients in Group A and Group B respectively.

Prior written consent of the patients was taken before administering the drug and clearance from Institutional Ethical Committee, Govt. Ayurvedic College and hospital, Guwahati (bearing reference number I.E.C/15, 20-65) was also obtained.

Trial methodology: Randomized Open Trial

\section{Diagnostic criteria}

1. History of Diabetes with any of the following signs and symptoms.

a. Karapada Daha (Burning pain) in Hands \& legs.

b. Cumcumayana (Tingling sensation) in Hands \& legs.

c. Dourbalya (Muscle weakness) in Hands \& legs.

d. Suptata (Sensory loss) in Hands \& legs.

2. Physical examination:

a. Muscle strength and Reflexes.

b. Sensitivity for touch, light touch, temperature, vibration, position change and pain.

\section{Inclusion criteria}

Patients of either sex of age group between 30 to 70 . T1DM \&T2DM with peripheral neuropathy, both newly diagnosed \& treated patients.
Patients with controlled blood sugar for a period of more than 1year.

\section{Exclusion criteria}

Patients with other metabolic and endocrine diseases.

Patients with autonomic, proximal and focal neuropathic state.

Neuropathy due to unknown cause or cause other than diabetes.

Patients with wound/ulcer or other infections.

Patients with other acute or chronic complications of Diabetic like nephropathy, ketoacedosis and gangrene etc.

\section{Investigations}

Fasting blood sugar (FBS)

Postprandial blood sugar (PPBS)

Glycosylated hemoglobin (HbAlc)

Urine for albumin, sugar, ketone bodies, microscopy.

Other required investigations-if necessary.

\section{Intervention}

In Group A, patients were given Guduchyadi kwath at the dose of $40 \mathrm{ml}$ twice daily after meal while in Group B, patients were given tablet Methylcobalamine $(500 \mathrm{mcg})+$ Gabapentine (300mg), 1 tablet daily after meal for a period of 3months with 6 follow ups at the interval of 15 days each.

\section{Drug Material}

Name of the drug: Guduchyadi kwath.

Ingredients: Stem of Tinospora cordifolia (Guduchi), bark of Prunus cerasoides D.Don (Padmak), wood of Pterocarpus santalinus Linn. (Rakta chandan), bark of Azardirachta indica A. Juss (Nimba) and seeds of Coriandrum sativum Linn. (Dhanyak), mixed in equal quantities.

\section{ASSESSMENT OF RESULTS}

\section{Subjective Assessment}

Clinical improvement of the symptoms like burning or pricking or aching pain, tingling sensation, muscle weakness, sensory impairment etc.

\section{Objective Assessment}

Appreciation of vibration test by $128 \mathrm{~Hz}$ tuning fork.

Filament test by using 10 grams monofilament.

Pin prick test.

Nerve Conduction Study (NCS)

Toronto clinical scoring system for DPN (TCS)

Monofilament Testing ${ }^{12}$ : For this examination, it is important that the patient's foot be supported (i.e., allow the sole of the foot to rest on a flat, warm surface). The filament should initially be pre stressed (4-6 perpendicular applications to the dorsum of the examiner's first finger). The filament is then applied to the dorsum of the great toe midway between the nail fold and the DIP joint. The filament is applied perpendicularly and briefly, $(<1$ second) with an even pressure. When the filament bends, the force of 10 grams has been applied. The patient, whose eyes are closed, is asked to respond yes if he/she feels the filament. Eight correct responses out of 10 applications is considered normal: one to seven correct responses indicate reduced sensation and no correct answers translates into absent sensation.

Appreciation of vibration test ${ }^{12,13}$ : - The foot of a vibrating tuning fork of $128 \mathrm{~Hz}$ should be placed below the great toe \& 
when the patient ceases to feel it, it is placed immediately as same in the examiner. Then the extra time for which vibration is felt by the examiner is documented. The less the difference of appreciation of vibration between the patient \& the examiner, better the results.

Pin prick test: Pain was tested by cutaneous stimulus with the help of light pin prick. The pins used were adequately sterile. Pressure pain examined by squeezing a distal muscle of the Achilles tendon.
Toronto clinical scoring system for $\mathrm{DPN}^{14}$ : This scoring system takes 6 symptoms, 2 reflexes and 5 sensory tests into consideration. Symptom scores graded as present-1; absent-0. Reflex scores graded as absent-2; reduced-1; normal-0 for each side and sensory test scores graded as abnormal, 1; normal,0. Maximum score is 19. Patients with 0-5 points are presumed to have no neuropathy, 6-8 points, mild neuropathy, 9-11points, moderate neuropathy and those with 12-19 points are presumed to have severe neuropathy.

Table 1: Toronto clinical scoring system for DPN ${ }^{14}$

\begin{tabular}{|c|c|c|}
\hline Symptom scores & Reflex scores & Sensory test scores \\
\hline Foot pain & Knee reflexes & Pinprick \\
Numbness & Ankle reflexes & Temperature \\
Tingling & & Light touch \\
Weakness & & Vibration \\
Ataxia & & Position \\
Upper limb symptoms & & \\
\hline
\end{tabular}

\section{Criteria for withdrawal}

The patients were withdrawn from the study if any serious complications develop which requires urgent treatment during the study.

Evidences of hyperglycemia or hypoglycemia in a patient of previously controlled blood sugar at any stage during the study.

\section{OBSERVATION AND RESULTS}

Demographic profile: In the present study, maximum number of patients, i.e. $40.48 \%$ belonged to the age group 51 to $60 \mathrm{yrs}$, were female $(54.76 \%)$, Muslims $(57.14 \%)$ Housewives by profession $(38.10 \%)$, from urban area $(66.67 \%)$ were non vegetarian $(92.86 \%) .40 .47 \%$ were from lower middle class, $54.76 \%$ had positive family history and $52.38 \%$ were having chronicity of 5-8 yrs. Majority of the patients i.e. 53\% were having Vata-kapha prakriti, $59.52 \%$ of patients were having Vishama agni and $59.52 \%$ of patients had Madhyam Kostha.

Clinical profile: Among the symptoms $80.95 \%$ had Karapada daha, $64.28 \%$ had Karapada supti, $69.04 \%$ had Chumchumayana, $40.47 \%$ had Shoola and $30.39 \%$ had Daurbalya as symptoms of neuropathy. In case of associated signs Diminished Vibration sensation was observed in all 100\% patients while Diminished Monofilament sensation was found in $45.24 \%$, Impaired pin sensitivity was found in $52.38 \%$ and $33.33 \%$ patients had Diminished Deep Tendon Reflexes.

Statistical analysis: The obtained information was analyzed statistically in terms of mean score (x), Standard Deviation (S.D.), Standard Error (S.E.). Paired' $t$ ' test and unpaired' $t$ ' test were carried out. The results obtained is presented in the tables and figures given below-

Table 2: Effect of the Trail drug on Subjective and Objective parameters of DPN in Group A

\begin{tabular}{|c|c|c|c|c|c|c|}
\hline \multirow{2}{*}{ Signs and Symptoms } & \multicolumn{2}{|c|}{ Mean Score } & \multirow{2}{*}{ SD } & \multirow{2}{*}{ PE } & \\
\cline { 2 - 6 } & BT & AT & & 0.12 & 6.04 & $<0.001$ \\
\hline Karapada daha & 1.63 & 0.88 & 0.61 & 0.14 & 2.12 & $<0.05$ \\
\hline Karapada supti & 1.0 & 0.71 & 0.67 & 0.14 & 2.85 & $<0.01$ \\
\hline Chumchumayana & 1.04 & 0.62 & 0.72 & 0.12 & 0.89 & $>0.10$ \\
\hline Shoola & 0.94 & 0.83 & 0.61 & 0.10 & 2.00 & $>0.10$ \\
\hline Daurbalya & 0.83 & 0.62 & 0.51 & 0.12 & 2.41 & $<0.02$ \\
\hline Monofilament test & 1.08 & 0.79 & 0.58 & 0.12 & 0.89 & $>0.10$ \\
\hline Deep tendon reflexes & 0.75 & 0.64 & \pm 0.61 & 0.09 & 2.14 & $<0.05$ \\
\hline Pinprick test & 0.92 & 0.21 & 0.41 & 0.42 & 9.8 & $<0.001$ \\
\hline Vibration test & 16.12 & 12.01 & 2.07 & 0.27 & 5.42 & $<0.001$ \\
\hline
\end{tabular}

BT- Before treatment, AT- After treatment, SD- Standard deviation, SE- Standard error.

Table 3: Effect of the Control drug on Subjective and Objective parameters of DPN in Group B

\begin{tabular}{|c|c|c|c|c|c|c|}
\hline \multirow[t]{2}{*}{ Signs and Symptoms } & \multicolumn{2}{|c|}{ Mean Score } & \multirow[t]{2}{*}{ SD } & \multirow[t]{2}{*}{ SE } & \multirow[t]{2}{*}{$\mathbf{t}$} & \multirow[t]{2}{*}{$\mathbf{P}$} \\
\hline & BT & AT & & & & \\
\hline Karapada daha & 1.44 & 0.67 & 0.73 & 0.17 & 4.47 & $<0.001$ \\
\hline Karapada supti & 1.06 & 0.67 & 0.50 & 0.11 & 3.53 & $<0.01$ \\
\hline Chumchumayana & 0.94 & 0.17 & 0.81 & 0.19 & 4.05 & $<0.001$ \\
\hline $\begin{array}{c}\text { Shoola } \\
\end{array}$ & 1.0 & 0.44 & 0.61 & 0.14 & 4.0 & $<0.001$ \\
\hline Daurbalya & 0.94 & 0.72 & 0.55 & 0.13 & 1.70 & $>0.10$ \\
\hline Monofilament test & 0.94 & 0.56 & 0.50 & 0.11 & 3.53 & $<0.001$ \\
\hline Deep tendon reflexes & 0.94 & 0.72 & \pm 0.59 & 0.14 & 1.5 & $>0.10$ \\
\hline Pinprick test & 1.0 & 0.67 & 0.64 & 0.15 & 2.20 & $<0.05$ \\
\hline Vibration test & 13.66 & 9.05 & 2.83 & 0.66 & 6.9 & $<0.001$ \\
\hline Toronto clinical score & 6.5 & 5.06 & 1.04 & 0.25 & 5.84 & $<0.001$ \\
\hline
\end{tabular}




\section{COMPARATIVE EFFECT OF THE TWO GROUPS}

Table 4: Comparative effect on signs and symptoms in Group A and Group B

\begin{tabular}{|c|c|c|c|c|c|}
\hline & $\overline{\mathbf{x}_{\mathbf{A}}}$ & $\overline{\mathbf{x}}$ & $\mathbf{S E}$ & $\mathbf{t}$ & $\mathbf{P}$ \\
\hline Karapada daha & 0.75 & 0.77 & 0.21 & 0.09 & $>0.10$ \\
\hline Karapada supti & 0.29 & 0.38 & 0.18 & 0.50 & $>0.10$ \\
\hline Chumchumayana & 0.42 & 0.77 & 0.24 & 1.45 & $>0.10$ \\
\hline Shoola & 0.11 & 0.56 & 0.18 & 2.50 & $<0.02$ \\
\hline Daurbalya & 0.21 & 0.22 & 0.17 & 0.06 & $>0.10$ \\
\hline Monofilament test & 0.29 & 0.38 & 0.16 & 0.54 & $>0.10$ \\
\hline Deep tendon reflexes & 0.11 & 0.22 & 0.18 & 0.61 & $>0.10$ \\
\hline Pinprick test & 0.21 & 0.33 & 0.17 & 0.71 & $>0.10$ \\
\hline Vibration test & 4.12 & 4.61 & 0.79 & 0.62 & $>0.10$ \\
\hline Toronto clinical score & 1.46 & 1.44 & 0.36 & 0.06 & $>0.10$ \\
\hline
\end{tabular}

$\overline{\mathbf{x}}_{\mathrm{A}}$-Difference in before and after treatment mean in Group A, $\overline{\mathbf{x}}_{\mathrm{B}}$-Difference in before and after treatment mean in Group B.

\section{DISCUSSION}

In the present study the development of Diabetic Neuropathy from Madhumeha has been highlighted under a triangular approach of Prakriti - Adhishtana - Samutthana ${ }^{15}$ with samprapti as a denominator. Again Madhumeha has been tried to be represented under three stages i.e. stage before madhumeha, during madhumeha and after madhumeha with Upadrava, taking dosha, dushya, ama, agni and srotas into consideration.

The pathogenic factors involved in the genesis of DPN areTridosha prakopa, Dhatukhsaya and Snayu sotha.

If we see the literature of counter part of modern medicine, that gives a similar picture of diabetic neuropathy. It is supposed that small nutrient vessels (vasa nervosum) which provide nutrition to nerves, become occluded (i.e. srotorodha occurs - which is one of the chief causes of Vata-prakopa). This leads to deficiency in nutrition of nerves (i.e. deficiency in Tarpana of snayu-snayugata Tarpaka kapha ksaya). Ultimately deficient nutrition of nerves leads to axon degeneration and demyelination of nerve sheaths and thus diabetic neuropathy is produced. Here axon degeneration and demyelination of nerve sheath may be attributed to vata prakopa and kapha kshaya. Normalcy of Vayu is needed for proper healing, growth and proper maintenance of tissue. Degenerative changes are seen generally due to vata prakopa, similarly kapha is also responsible for the maintenance of normalcy of tissues. So we may say that axon degeneration and demyelination of nerve sheath is due to Vata prakopa and kapha kshaya.

In a diabetic patient, the usual pathway of glucose metabolism (i.e. via Glucose -6- $\mathrm{PO}_{4}$ ) becomes depressed and sorbitol pathway becomes predominant. The enzyme sorbitol dehydrogenase acquires more rapid action and as a result, sorbitol and fructose are formed in excess and become accumulated in tissues which causes damage to nerve tissue and produces axon degeneration which leads to neuropathy. This rapid rate of activity of enzyme sorbitol dehydrogenase may be attributed to Pitta vriddhi. Thus, involvement of Tridoshas is apparent in diabetic neuropathy. ${ }^{16}$

In the present study, maximum number of patients, i.e. $40.48 \%$ belonged to the age group 51 to 60 yrs. This age group have predominance of vata dosa with poor sharira bala, dhatu and oja and people are susceptible to vatik disorders. Since DPN is a Vata predominant disorder, so is more prominent among age group 51-60yrs as observed in the present trail. This finding is similar to Pittsburgh epidemiology study of diabetes where $58 \%$ of diabetics above 50yrs of age had Diabetic neuropathy.
Female gender dominance is seen in the present study and maximum patients were housewives. Sedentary life style, day sleep, poor compliance to anti diabetic treatment and stress are common in housewives leading to poor glycemic control and development of neuropathy eventually. Most of the patients were from lower middle class, which reflects the increasing substantial sedentary habits among the people of lower middle class which is no longer limited only to the people of upper and middle class. It is worth mentioning that these diabetic patients from lower class are at high risk of insensate injury of feet due to improper foot care leading eventually to Diabetic foot ulcer. Maximum no. of patients i.e. $54.76 \%$ had positive family history as genetic factors are known to play role in Diabetes and also Diabetic neuropathy. Researchers have isolated genes like 5'ALDR2 which are thought to play crucial role in the development of DN. 52.38 \% were having chronicity of 5-8 yrs followed by $23.80 \%$ having between $9-12$ years. Chronicity of the disease Madhumeha plays an important role in the development of complications esp. Diabetic neuropathy as its incidences are directly proportional to chronicity. Greater the chronicity, greater the Dhatu Kshaya leading to Vata prakopa. Some important findings which came out during the clinical study in patients of the two groups are presented below:

\section{Group A (Trail group)}

All the patients presented with varied degree of lakshanas.

The drug proved to be significantly effective for symptoms like karapada daha, karapada supti, chumchumaya and signs of Vibration sensation, Monofilament test and Pin prick test. Insignificant results were obtained with symptoms of Daurbalya and Shoola. In case of signs insignificant changes were seen in Deep tendon reflexes.

The overall Toronto clinical score for Diabetic neuropathy was also significantly improved.

No incidence of hypoglycaemia was seen in any patient. No drug related adverse effect was observed in any patient. It was observed that there was considerable improvement in the feeling of generalized well being on their neurophysiologic activities after the therapy.

\section{Group B (Control group)}

All the patients presented with varied degree of lakshanas. Significant results were obtained for symptoms of karapada daha, karapada supti, chumchumaya, shoola and signs of Vibration sensation, Monofilament test and Pin prick test. Insignificant results were obtained with symptoms of Daurbalya. In case of signs insignificant changes were seen in Deep tendon reflexes.

The overall Toronto clinical score for Diabetic neuropathy was also significantly improved. 
No incidence of hypoglycaemia was seen in any patient.

No severe drug related adverse effect was observed in any patient though few patients complained of occasional giddiness during the course of therapy which was previously absent.

The formulation Guduchyadi Kwath has been mentioned under Jwara Rogadhikara by Sadangadhar ${ }^{17}$ and Bheshjya Ratnavali ${ }^{18}$. For the genesis of Diabetic neuropathy, the vitiated vayu carries away Pitta from its normal site i.e. Mahasrotas leading to Vimargagamana of Vyana vayu and Pitta which after spreading to the whole body does Sthana samsraya in Twacha and produces various features according to anubandha. Since this samprapti is very much similar to Jwara samprapti hence Guduchyadi Kwath which is mentioned under Jwara Rogadhikara, acts precisely on Diabetic Neuropathy by doing Samprapti Vighatan. It is also Tridosha shamak chiefly PittaKapha shamak. As mentioned before Diabetic neuropathy is a Vatapradhana Tridoshaja vyadhi with manifestation of symptoms according to anubandha with Pitta and Kapha. Hence action of the drug as far as doshakarma is concerned, is justified. Snigdha and Guru guna of the drug act against Vata. Among the five herbs, Rakta chandan, Padmak and Nimba are having Sheeta Virya while Guduchi and Dhanyak have Ushna virya. The Sheeta virya acts against Pitta anubandhatva which produced symptoms like daha etc while the Usna virya tackles Kapha anubandhatva which produced features of supti, shaitya, chumchumayana etc. Ushna veerya and snigdha guna of guduchi and dhanyak makes it vata shamak, deepan and pachak as well. All the plants in the composition except Dhanyak have Dahaprashamana ${ }^{19}$ karma which acts against Karapadatala daha which was observed to be the most common occurring symptom among the patients enrolled in the present study. Other karmas like Vedana sthapak, Raktashodhak, Srotovishodhana ${ }^{20}$ acts for disruption of samrapti at various levels. Dipana and pachana karma causes agni sandukshana which is at the root of genesis of the disease Prameha. Since the drugs are Vrishya ${ }^{21}$, Rasayana and Balya, hence help in the correction of Dhatukshaya and Ojakshaya. Thus Tridoshashamaka property of this drug helped to correct the Dhatudushti and Srotodushti leading to their normal functioning. Moreover, a study has shown that Ethanolic extracts of Tinospora cordifolia demonstrated a significant increase in the tail flick reaction time in Wistar albino rats at doses of 100 and $200 \mathrm{mg} / \mathrm{kg}$ b.w. $(\mathrm{p}<0.05)$ as compared to the Control group ${ }^{22}$. In-vitro aldose reductase inhibition was observed with TC with an $\mathrm{IC}_{50}$ of $103 \mathrm{mcg} / \mathrm{ml}^{22}$ and also showed effective and high levels of evidence for its action against Diabetic neuropathy, gastropathy and Diabetic foot ulcer ${ }^{23}$. Guduchi also has been extrapolated to have strong neuroprotective activity against oxygen and glucose deprivation ${ }^{24}$.

Oral treatment of diabetic rats with Azadirachta indica $(500$ $\mathrm{mg} / \mathrm{kg}$ of body weight) have been showed to lower the blood glucose level and also inhibited the formation of lipid peroxides and reactivated the antioxidant enzymes, in the abovementioned model. ${ }^{25}$ It is well known that oxidative damage is one of the most important factor in the genesis of DPN. All the ingredients of Guduchyadi Kwath are very good source of antioxidants. Pterocarpus santalinus Linn. has high content of pigments particularly carotenoids which show high hydroxyl radicals scavenging potential thereby protecting cells from oxidative damage (Peethambaran et al., 2012).

So in accordance with Prakriti Samsamaveta Sidhanta, Guduchyadi Kwath for the above mentioned qualities one specifically on kapha, meda, kleda and other on srota, kupita
Vata, Pitta and Kapha has been observed to have significant results in the treatment of DPN.

\section{CONCLUSION}

Although a common and important complication of diabetes, neuropathy has not been studied as often or as extensively as other micro-vascular complications or retinopathy and nephropathy. In addition, the reported prevalence estimates vary widely between countries, in part due to the difference in sampling methods and lack of consensus on diagnostic criteria. Though encouraging results were obtained with the trail drug but further studies are required to generate a matrix of scientific evidence at the clinical and pre-clinical levels, including chemical, cellular and animal studies, in order to develop effective medicines for the prevention and treatment of diabetic complications. As present study was conducted with limited time and on limited number of patients, further additional studies may be performed on this formulation for a longer duration and with bigger sample size.

\section{REFERENCES}

1. Dyck PJ, Kratz KM, Karnes JL, Litchy WJ, Klein R, Pach JM, Wilson DM, O'Brien PC, Melton LJ, 3rd, Service FJ.: The prevalence by staged severity of various types of diabetic neuropathy, retinopathy, and nephropathy in a population-based cohort: the Rochester Diabetic Neuropathy Study. Neurology 1993;43:817-824. http://dx.doi.org/ 10.1212/WNL.43.4.817

2. J.E. Shaw, P.Z. Zimmet, The epidemiology of diabetic neuropathy, Diabetes Rev. 7 (1999) 245-252.

3. A.J. Boulton, et al., Diabetic neuropathies: a statement by the American Diabetes Association, Diabetes Care 28 (2005) 956-962. http://dx.doi.org/10.2337/diacare.28.4.956

4. Watkins PJ: The natural history of the diabetic neuropathies. Q J Med 77:1209-1218, 1990. http://dx.doi.org/ 10.1093/qjmed/77.3.1209

5. Thomas Tolle et al., Painful diabetic neuropathy: a crosssectional survey of health state impairment and treatment patterns. Journal of Diabetes and Its Complications 20 (2006) $26 \quad-33 . \quad$ http://dx.doi.org/10.1016/j.jdiacomp. 2005.09.007

6. Peter J. Dyck, James W. Albers, Henning Andersen, Joseph C. Arezzo, Geert-Jan Biessels. Diabetic polyneuropathies: update on research definition, diagnostic criteria and estimation of severity. Diabetes Metab Res Rev 2011; 27: 620-628. http://dx.doi.org/10.1002/dmrr.1226

7. S. Yagihashi, Pathology and pathogenetic mechanisms of diabetic neuropathy, Diabetes Metab. Rev. 11 (1995) 193225. http://dx.doi.org/10.1002/dmr.5610110304

8. A.A. Sima, K. Sugimoto, Experimental diabetic neuropathy: an update, Diabetologia 42 (1999) 773-788. http://dx.doi.org/10.1007/s001250051227

9. D.R. Tomlinson, Mitogen-activated protein kinases as glucose transducers for diabetic complications, Diabetologia 42 (1999) 1271-1281. http://dx.doi.org/10.1007/ s001250051439

10. Charaka, Charaka Samhita, hindi commentary by Kashinath Shatri, 8th edition, reprint 2009, Chaukambha Bharati Academy, Varanasi, Chikitsa Sthana, chapter 4/47, p. 640.

11. Michael I Bennett and Karen H Simpson. Gabapentin in the treatment of neuropathic pain. Palliative Medicine 2004; 18: 5-11. http://dx.doi.org/10.1191/0269216304pm845ra

12. Perkins BA, Olaleye D, Zinman B, et al. Simple screening tests for peripheral neuropathy in the diabetes clinic. 
Diabetes Care.2001;24:250-6. http://dx.doi.org/10.2337/ diacare.24.2.250

13. Kastenbauer T, Sauseng S, Brath H, Abrahamian H, Irsigler $\mathrm{K}$. The value of the Rydel-Seiffer tuning fork as a predictor of diabetic polyneuropathy compared with a neurothesiometer. U.S. National Library of Medicine Diabet Med. 2004 June; 21(6):563-7.

14. B.A. Perkins, V. Bril, Diabetic neuropathy: a review emphasizing diagnostic methods. Clinical Neurophysiology 114 (2003) 1167-1175. http://dx.doi.org/10.1016/S13882457(03)00025-7

15. Charaka, Charaka Samhita, hindi commentary by Kashinath Shatri, 8th edition, reprint 2009, Chaukambha Bharati Academy, Varanasi, Sutra Sthana, chapter 18/45-46, p. 383.

16. Jaideep - A clinical study to evaluate the effect of an ayurvedic formulation in Diabetic Neuropathy,Academic Dissertation, H. P University, 2009.

17. Sharangdhar, Sharangdhar Samhita; Jivanprada hindi commentary by Shailaja Srivastava, Chaukhambha Orientalia, Varanasi, Madhyam Khanda Chapter 2/157- 8, p. 136.

18. Sen Gobindas, Bhaisajya Ratnavali; Vidyotini hindi commentary by Ambika Dutt Shastri,17th edition, 2012, Chaukhambha Prakhashan, chapter 5/156, p. 57.

19. Acharya Sushruta, Sushruta Samhita; Ayurved Tattva sandipika hindi translation by Ambika Dutt Shastri, 13th edition, Chaukhamba Sanskrit Sansthan, Varanasi Sutrasthan chapter 38/50-51, p.145.

20. Charaka, Charaka Samhita, hindi commentary by Kashinath Shatri, 8th edition, reprint 2009, Chaukambha Bharati Academy, Varanasi, Sutra Sthana, chapter 25/40, p. 469.
21. Bhavamishra, Bhavaprakash Nighantu; Vidyotini hindi commentary by Brahmasankara Mishra, 11th edition: 2007, Chaukhambha Prakhashan, Part-1, Karpuryadi varga/ 16-17, p. 191.

22. Pratibha D. Nadig, Roshni R. Revankar. Effect of Tinospora cordifolia on experimental diabetic neuropathy. Indian $\mathrm{J}$ Pharmacol. 2012 Sep-Oct; 44(5): 580-583. http://dx.doi.org/ 10.4103/0253-7613.100380

23. Eshaifol A. Omar.et.al.Herbal Medicines and Nutraceuticals for Diabetic Vascular Complications: Mechanisms of Action and Bioactive Phytochemicals. Current Pharmaceutical Design, 2010, 16, 3776-3807. http://dx.doi.org/ 10.2174/138161210794455076

24. Rawal AK, Muddeshwar MG, Bisis SK. Rubia cordifolia, Fagonia cretica linn and Tinospora cordifolia exert neuroprotection by modulating the antioxidant system in rat Hippocampal slices subjected to oxygen glucose deprivation. BMC Complement Altern Med. 2004; 4: 11. http://dx.doi.org/10.1186/1472-6882-4-11

25. Anu Chandra, Abbas Ali Mahdi, Raj Kumar Singh, Farzana Mahdi, and Ramesh Chander. Journal of Medicinal Food. September 2008, 11(3): 506-512. http://dx.doi.org/10.1089 /jmf.2007.0042

\section{Cite this article as:}

Rehana Parveen, B. P. Sarma. A clinical study to evaluate the efficacy of Guduchyadi kwath in the management of Diabetic polyneuropathy. Int. J. Res. Ayurveda Pharm. Mar - Apr 2016;7(2):17-22 http://dx.doi.org/10.7897/2277-4343.07248

Disclaimer: IJRAP is solely owned by Moksha Publishing House - A non-profit publishing house, dedicated to publish quality research, while every effort has been taken to verify the accuracy of the content published in our Journal. IJRAP cannot accept any responsibility or liability for the site content and articles published. The views expressed in articles by our contributing authors are not necessarily those of IJRAP editor or editorial board members. 